\title{
Liberalization and Rural Market Integration in China
}

\section{Scott Rozelle, Albert Park, Jikun Huang, and Hehui Jin}

In the early $1990 \mathrm{~s}$, leaders allowed market liberalization to proceed in food markets. During this time, markets burgeoned with grain. Faced with tight budgets, leaders saw an opportunity to make the economy more efficient and at the same time reduce government fiscal obligations. Urban grain reforms phased out rationing and provided incentives for city grain retailers, who had been ration shop bureaucrats, to engage actively in market trade (Watson). These policy shifts were closely followed by a series of rural marketing reforms, and, for the first time in many decades, transactions among private and commercialized traders accounted for most of the movement of China's food. While the initial implementation of liberalization policies was considered by most to be successful (Chen 1994b), during the rapid food price inflation in 1994 officials attempted to reverse some of the reforms. A perception of loss of control over agricultural commodity circulation has led to a reassessment of the progress of China's market reform program (Duan).

Policy makers and academics have vigorously debated the reasons for successes and failures of the liberalization of food markets and the implications for future policy reform. Some argue that the recent breakdown in agricultural pricing policy calls into question the commitment the government should make to re-

\footnotetext{
Scott Rozelle is associate professor in the Department of Agricultural and Resource Economics at the University of California, Davis. Albert Park is assistant professor in the Department of Economics at the University of Michigan. Jikun Huang is director of the Center for Chinese Agricultural Policy, Chinese Academy of Agricultural Sciences. Hehui Jin is research fellow at the Rural Development Institute, Chinese Academy of Social Science.

The authors have benefited greatly from discussions with Bob Baulch, Fred Crook, Marcel Fafchamps, Wally Falcon, John McMillan, Barry Naughton, Al Nyberg, Xiaopeng Luo, Jean Oi, Terry Sicular, and Jeffrey Williams. The authors acknowledge the support of the International Development Research Center, the International Rice Research Institute, the International Food Policy Research Institute, and the China Division of the World Bank. The support of Stanford's Institute for International Studies and the Center for East Asian Studies is also gratefully acknowledged.
}

form, believing that market deregulation has undermined the leadership's ability to intervene in areas of vital national interest which still need to be regulated closely (Chen 1994a). Others, however, postulate that markets are working fine, and that it is the inability of regulatory agencies to effectively function within the newly commercialized environment that has undermined the government's policy influence (Chen 1994b, Park and Rozelle 1996). This debate reveals a dilemma in state-market relations facing government leaders. Should the leadership accept the new order in which markets are the primary mechanism for resource and goods allocation and focus its attention on developing a set of policy tools to influence economic behavior indirectly? Or, should China's leaders reverse the recent reforms and, despite inefficiencies, revitalize the plan-oriented state-marketing system to ensure low-priced food for urban residents?

The purpose of this paper is to analyze the transformation of China's rural marketing system, trying to understand how well China's rural grain markets are functioning after a period of intensive liberalizing reforms and decisive attempts to curb these actions. In addition to recounting recent rural reforms, we seek current empirical evidence on how liberalization has affected market development in China's transitional rural economy. The research draws upon extensive fieldwork since the late $1980 \mathrm{~s}$ in more than twenty provinces. Access to a unique and comprehensive set of data on provincial prices of major food commodities every ten days between 1988 and 1995 facilitates a rigorous testing of many of the insights gained during interviews. Finally, the impact of market integration on pushing producers to more effectively utilize their comparative advantage is analyzed. Understanding the microeconomic behavior of participants in the commercialization of China's food markets not only helps clarify the debate on state-market relations but also provides broader lessons for understanding 
the dynamics of transition and the creation of markets.

\section{Reform in China's Rural Markets}

Despite a series of fundamental changes in production decisions and the marketing system (Lardy, Sicular), reformers in the 1980 s had no intention of forfeiting control over key commodities such as grain to the market. Agricultural planners did little, even in the mid 1980s, to encourage grain bureau employees to take advantage of the potential profits from extraplan grain trade. Managers of grain bureaus found themselves with little incentive to trade grain. For example, most grain agencies could not engage in commercial activities beyond the sales of staple goods. Fixed, low urban ration prices dampened the demand for high-quality free-market food. When out-of-plan prices rose in 1988 and 1989 and grain shortages loomed, leaders directed grain officials to stabilize food supplies, pressuring producers to direct their marketed surplus through state channels, actively suppressing free-market trade, and blockading shipments to regions of the country which had ignored central government directives to maintain high levels of grain production (e.g., Guangdong Province). Leaders maintained high production levels with a multiplicity of policies such as mandatory delivery quotas, sown area targets, political rewards for high grain output, increased investment in infrastructure, and subsidies to producers (Rozelle 1994).

In the early 1990s, China's leaders were presented with a unique opportunity to deepen market reforms. Falling food prices, plentiful food stocks, and low grain imports provided the "slack" for accommodating new reforms. Agricultural officials sought to liberalize prices and markets as a way of raising the efficiency of China's food economy and to increase rural incomes. At the same time, budgetary pressures were growing. Even though the proportion of the budget allocated to food subsidies was fairly stable, the fiscal ability to bear these subsidies was falling, given difficulties in mobilizing revenues and growing expenditure demands, forcing budget managers at all levels to find ways to reduce expenditures. Under these circumstances, grain price subsidies came under scrutiny as a possible source of budgetary savings. Fiscal managers also could cut budgets by moving a large part of the three million employees in the grain system off the state's payroll.

Shortly after far-reaching changes to the ur- ban food system (Sicular, Rozelle et al.), the pace of grain market liberalization in rural areas also accelerated in the early 1990s. Policy makers reduced mandatory delivery quotas, eliminated the implicit tax on farmers by raising the procurement price to market levels, and increased commercialization of the grain system in rural areas.

Policy makers experimented with a new set of grain sector reforms in the early 1990s as prices fell and grain stocks expanded. In 1990, Guangdong Province officially eliminated all grain and oil seed quotas and directed grain stations to procure farmers' grain at the prevailing market price (Watson). In 1992, farmers in nearly $20 \%$ of China's counties (mostly in five provinces-Fujian, Shanghai, Zhejiang, Jiangsu, and part of Sichuan) eliminated mandatory quota deliveries (ZGSYNJ 1993).

While mandatory deliveries were not eliminated in most parts of the country, national grain officials did recommend that the implicit quota tax on farmers be removed. Farmers still had an obligation to sell a fixed amount of grain to local procurement stations, but under the new policy, the procurement price was supposed to be market-determined. While not implemented in all provinces, leaders pushed this policy to reduce the tax burden on farmers.

Low market prices for grain facilitated local compliance with the new policy to procure all grain at the market price. When the policy was announced in late 1992 and early 1993, the average price of rice and maize had been falling in real terms for over three years. The price for paddy rice in rural periodic markets in early 1993 was only $60 \%$ of its 1989 level. The implicit tax of quotas for major grains sank to only about $20 \%$ of the market price in 1992 from over $40 \%$ in the late $1980 \mathrm{~s}$. In 1992, some procurement stations even stopped accepting delivery of the mandatory procurement quota, because it was cheaper to buy grain on the market than at the announced quota price.

In a move paralleling actions in the cities, policy makers promoted commercialization of the procurement arm of the grain system. Beginning in 1992, officials converted prefectural and county grain bureaus and township grain stations into commercial trading companies. Although there is substantial regional heterogeneity, new contracts between the grain bureau and the division or station manager resembled those signed by retail shop managers in urban areas: they primarily were designed to provide rural grain bureau managers with an incentive to trade grain for profit. Grain companies were ex- 
pected to continue trading grain and oilseeds. They accepted responsibility for guaranteeing the employment of personnel and supporting retirees. In addition, they were expected to carry out certain policy functions such as the procurement of quotas (where they existed) and the handling of national and local grain buffer stocks. Depending on the amount of the subsidies for such activities, grain stations could earn a certain amount of steady revenue or, more commonly, be saddled with losses from policy-related operations. Trading companies, like other commercial concerns, were expected to cover operational expenses and pay income tax.

In return, grain managers were given control of state-owned assets (the most valuable of which were their storage facilities and fleets of trucks). Profit- and cost-sharing arrangements primarily served to elicit greater effort by managers and employees and increase efficiency. The share of profits available to the firm for bonuses, employee services and benefits, and reinvestment often were spelled out explicitly in new contracts. In a county in Guizhou, for example, $100 \%$ of the pay of managers and workers came from the county budget in 1993 . By agreement, this percentage was reduced to $70 \%$ in 1994 and to $50 \%$ in 1995 . Under the contract, grain stations retained $50 \%$ of profits for bonuses, services, and benefits. The other $50 \%$ was used to offset some of the losses from policy operations.

\section{Initial Success, Price Rises, and Retrenchment}

One of the most significant aspects of the immediate impact of the numerous liberalization reforms was that "nothing" happened. There were no sharp disequilibriumizing effects accompanying market liberalization measures as in Eastern Europe and the former Soviet States, where food shortages emerged and agricultural output and incomes in a number of countries fell by more than 50\% ( $\mathrm{Lin}, \mathrm{Cai}$, and $\mathrm{Li}$ ). Instead, food prices in the early 1990s stayed constant or even declined in real terms. There were no major shortages in either urban or rural markets. Production expanded in 1993 and grain imports fell dramatically after 1989. Even accounting for the direct wage subsidies provided by the state to urban workers to compensate for higher food prices, in 1992 the proportion of the national budget used for food subsidies fell below $10 \%$ for the first time since 1978 (Rozelle et al.). Because of the nearly seamless initial transition, the scope of the changes and the extent of the reform efforts went largely unnoticed during the initial years after implementation.

The success of market liberalization in the early 1990s was downplayed when food prices began to rise rapidly in December 1993 and continued increasing throughout the winter and spring of 1994. From late 1993 to mid 1994, the average nominal price of rice in rural periodic markets rose more than $70 \%$, from 1.30 yuan per kilogram to 2.30 yuan. Prices in key urban centers rose faster, nearly $80 \%$ in Shanghai and over $90 \%$ in the markets around Shenyang, Wuhan, and Guangzhou. Inflationadjusted real prices of rice and maize also rose, but at a slower rate. Between late 1993 and the middle of 1995 , real rice prices rose by $75 \%$ and those of maize rose by about $60 \%$.

Since food still accounts for about $50 \%$ of consumption expenditures by urban residents and nearly $60 \%$ of the average rural consumption bundle, leaders perceived the rapid rise in food prices as a threat to overall price stability (Chen 1994b, Duan). Despite calls by some scholars and agricultural officials to allow farmers to enjoy the income increases which would come with higher grain prices (Chen 1994b, Duan), the political and economic importance of maintaining an abundant supply of low-cost food for urban workers induced the State Council to take action to curb food price inflation beginning in the first half of 1994. Price controls were imposed in urban areas, and rationing of state grain sales was reintroduced. Procurement quotas at below market prices were reintroduced in rural areas. Just as in the late 1980s, national and regional leaders called on grain stations to release state grain stocks at certain predetermined, below-market prices and take measures to halt the movement of grain out of surplus areas to dampen local prices and put pressure on deficit area consumers and their officials.

These policies, however, failed to achicve the government's stabilization goals (Wu). Price controls in some cities led to shortages. In response to the faltering supply, some officials chose not to enforce the regulations. In other municipal regions, maximum price limits were quickly raised because of the fear of prolonged shortages. Unlike previous years, many procurement quota obligations were not fulfilled. Some raised doubts as to the effectiveness of calls to block shipments to deficit areas. There was a consensus by some that traditional policy instruments had lost their effectiveness in controlling the flow of China's major commodities (Duan). 
One explanation for lost control of the grain economy is that institutional changes led commercialized, quasi-government trading companies to pursue profits and evade orders to stop grain shipments or execute unprofitable buffer stock operations (Park and Rozelle). Leaders in a number of provinces (such as Henan) reported that some grain station managers resisted selling government stocks at low prices to defend price ccilings for fear of having to bear the cost of such policy operations or to avoid reducing the profitability of their own trade since sales of buffer stocks might lower market prices and devalue their stocks of trade grain. In one case in Guizhou, a county grain station could not release government buffer stocks because the grain had already been shipped illegally to Guangdong for a hefty profit. In other cases, interviewed field agents from local grain bureaus only reluctanlly collected quotas from farmers since as traders they did not want to alienate those who might want to sell them grain later in the year.

Other reports, however, cast doubt upon the progress of China's effort to develop rural markets. Some do not believe initial claims of rapidly integrating markets because of the fragmented nature of China's infrastructure (Wan and Cheng). Others suggest that, regardless of the temporary improvement in market development, implementation of restrictive policies, such as the Governor's Responsibility System and Provincial Rice Bag measures, reversed the gains (Huang).

\section{Impact of Liberalization on Market Development}

This section presents evidence on the impact of the economic policies implemented in the early 1990 s on market integration, the cost of transacting interregional grain trade, and the response of producers. The hypothesis that retrenchment policies reversed efforts to improve the competitiveness of rural China's markets is examined.

\section{Market Integration}

Marketing and price reforms led to a striking increase in the integration of rural China's commodity markets. Falling coefficients of variation (CVs) for provincial rice and maize prices from 1988 to 1993 imply that price variation among markets fell, one sign of increasing integration (figure 1). Statistical tests of the change in variance measures show that the average variances for the two series are significantly lower in 1991-93 than in 1988-89. Average rice and maize price differences among provinces also have fallen steadily (Rozelle et al.). By these measures, the reforms in the early 1990s appear to have succeeded in increasing grain market integration.

More formal tests of market integration (provided by cointegration analysis) support these results. Most rice and maize markets have become increasingly integrated after liberalization policies of the early 1990s. The number of pairs of provinces that became integrated went up by more than four times between 1988-89 and 1991-93 for rice markets and more than doubled for maize markets. These increases re-

Panel A: Rice

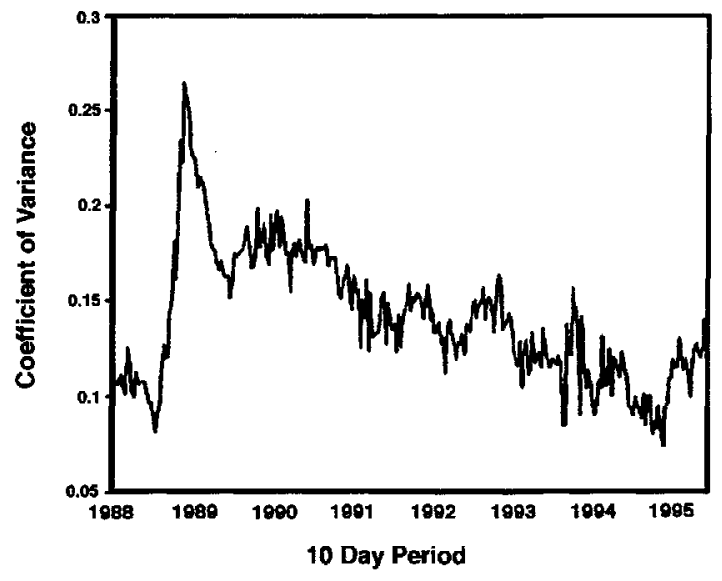

Panel B: Maize

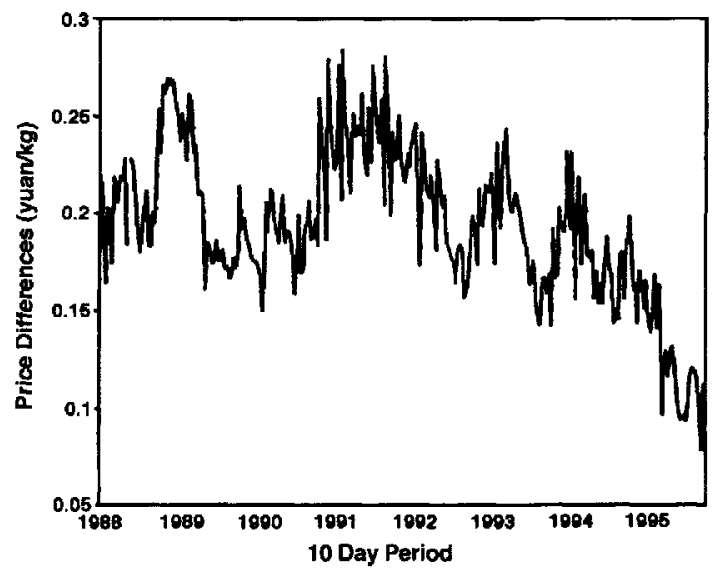

Source: Market Adrninistration Bureau Rural Market Survey

Figure 1. Coefficients of variation among provinces of nominal prices of grain in rural markets in China, 1988-95 
Table 1. Results of Parity Bounds Analysis on the Development of Rice and Maize Markets in Rural China, 1988 to 1995

(1)

Proportion of Successful

Arbitrages when Arbitrage Opportunities Exist (L)
Transaction Cost of Moving

Grain from Buying

to Selling Province (T)

(Yuan per Kilogram)

Time Periods $^{\mathrm{a}}$

0.58

$(0.11)^{\mathrm{b}}$

1990-91

1992-93

1994-95
0.62

$(0.25)$

0.70

$(0.15)$

0.69

$(0.21)$
0.19

$(0.03)$

0.17

$(0.02)$

0.17

$(0.03)$

0.25

(0.04)

Maize
1988-89
0.69
0.20
$(0.12)$
(0.02)
1990-91
0.83
0.17
(0.11)
(0.01)
1992-93
0.83
0.12
$(0.09)$
(0.01)
1994-95
0.67
0.14
$(0.20)$
(0.02)

Source: Data are from National Market Administration Bureau's (NMAB) Rural Periodic Market Survey. Prices are reported every ten days from a number of markets in each province. Statisticians from NMAB aggregate the market-level data into a provincial arithmetic average.

Note: Rice sellers include Hunan, Hubei, Jiangxi, Anhui, and Jiangsu. Rice buyers include Zhejiang, Guangdong, Guangxi, Guizhou, Yunnan, and Sichuan. Maize sellers include Jilin, Liaoning, Inner Mongolia, Hebei, Henan, Shandong, Shanxi, and Shaanxi. Maize buyers include Zhejiang, Guangdong, Guangxi, Hunan, Guizhou, Yunnan, and Sichuan. Figures are the "average of all markets," and are calculated by taking the average of the results of analysis of market development of each of the sellers with each of the buyers. The results are averages of 30 regressions ( 5 sellers and each of their 6 buyers).

a The periods span from the planting period in the year before the given year until the harvest of the second year (e.g., the period 1990 spans the marketing periods from November 1989 to October 1991).

${ }^{b}$ Standard crrors are reported in parentheses.

flect an expanding geographic range of spatial market integration.

Parity bounds analysis (Sexton, Kling, and Carman) confirms this finding (table 1 , columns 1). The proportion of times that rice traders were able to achieve arbitrage, given an opportunity to do so, increased from $58 \%$ in the $1988-89$ period to $70 \%$ in $1992-93$ (rows 1 and 3). Maize market integration increased from $69 \%$ to $83 \%$ (rows 5 and 7 ).

Most of the gains in commodity market integration in the early post-liberalization period were not lost after the onset of the retrenchment policies in 1994. The coefficients of variations in rice only rise minimally, and those of maize continue to fall (figure 1). According to cointegration analysis, rice markets integration actually increased in the post-retrenchment period. Parity bounds analysis also shows that rice market integration does not fall in the post
1994 period (table 1, column 1, rows 3 and 4). And, while integration in maize markets abates somewhat, closer analysis shows most of the drop was due to falling integration in several of the inland provinces (Rozelle et al.). The integration of coastal provinces increases between the 1992-93 and 1994-95 periods.

\section{Market Efficiency: The Cost of Commodity Exchange}

Parity bounds analysis demonstrates that the liberalization policies in the early 1990 s coincide with the improvements of markets in another dimension. The average cost of moving rice between markets in the early $1990 \mathrm{~s}$ dropped to 0.17 yuan per kilogram from 0.19 yuan in the late 1980 s (table 1 , column 2, rows $1-3)$. The fall in the average transaction cost of 
transporting maize among its major buyers and sellers fell even sharper, from 0.20 yuan in the late $1980 \mathrm{~s}$ to 0.17 in $1990-91$ and 0.12 in 1992-93. Part of the reason for this fall in the cost of exchange may have arisen from the increased capacity to ship grain due to the rapid construction of rail, roads, and ports (Nyberg). However, it is equally likely that the rise in the demand for transportation may have put even greater pressure on transport costs (ZGTJNJ 1995). Expanding rural market infrastructure (Sicular 1995), developing networks of traders, and increasing competition among grain traders (Rozelle et al.) also would contribute to falling interregional transaction costs.

The same analysis, however, illustrates that one of the largest costs of the 1994-95 retrenchment policies may have been in rising transaction costs, especially in the case of rice (table 1, column 2). The average cost of moving rice between buyers and sellers increased from 0.17 yuan in 1992-93 (immediately after liberalization) to 0.25 yuan in 1994-95 (after retrenchment), a level above that of the late 1980 s. At this level, approximately one-quarter of the final cost of rice is attributable to transaction costs, a level much higher than that of a more developed country like the United States where similar marketing margins range from $3 \%$ to $10 \%$. Hence, Zhong (1994) may have been accurate when he observed that grain policy did not keep the post-retrenchment, quasi-commercialized grain traders from continuing their trade; it only increased the cost. Grain traders still had an incentive to take advantage of arbitrage opportunities, but retrenchment measures could have made it more costly to trade rice. The increase in maize transaction costs was more moderate, only 0.02 yuan (from 0.12 to 0.14 -column 2 , rows 7 and 8 ).

\section{Increases to Producer Efficiency}

One successful indicator of market liberalization would be if improving markets induced producers to cultivate crops in which they had a comparative advantage. Following Park, Rozelle, and Cai (1994), crop yields ratios are used as indicators of comparative advantage. While such use is questionable given the endogeneity of yields to labor and other input decisions, yield differences can still help predict optimal changes in future sown area decisions, assuming less than instantaneous adjustment or adaptive expectations by farmers. These changes should narrow the spread in observed yield ratios since increasing area devoted to a relatively high yielding crop will make the inputs in which it is intensive more scarce, improving the relative return of the other crop. A test for comparative advantage is that, with increasing opportunities for specialization (e.g., after liberalization), changes in relative sown area ratios should be positively correlated with previous period yield ratios.

Figure 2 illustrates the results conducted to test this hypothesis for two grain crops (rice and maize) and one cash crop (peanuts). During the late 1970s and early 1980s (after decollectivization), correlations for provincial data mostly range from 0.40 to 0.20 . Most of these measures are statistically different from zero at the $10 \%$ level. In contrast, in the late 1980 s, there was no appreciable response (coefficients were between -0.20 and 0.20 ) as the adjustment of the initial reforms was completed, and markets were still heavily influenced by planners (a result found by Park, Rozelle, and Cai). After the onset of the liberalization reforms, however, the rank correlations for all crops begin to rise. By 1992-93 those for rice, maize, and peanuts are mostly above 0.30 . Liberalization policies appear to have been successful in encouraging farmers to move into crops in which they have a comparative advantage.

\section{Conclusion}

The evidence above indicates that liberalization policies and the commercialization movement most likely have given grain trading firms an incentive to trade for profits and to shirk when carrying out policies which encroach on their income-generating activities. This success has created markets that are surprisingly integrated and increasingly efficient. Moreover, following the bold liberalization initiatives in the early 1990 s, the recent retrenchments did not work nearly as effectively as planners had expected. The grain economy has become commercialized to an unprecedented degree, and state grain traders were leading the move to commercialization. In fact the same institutional changes that introduced strong profit incentives which encourage market-integrating trading behavior also conflicted with the implementation of policies, such as price stabilization and grain redistribution.

Success in market liberalization and commercialization of state grain trade thus has created 

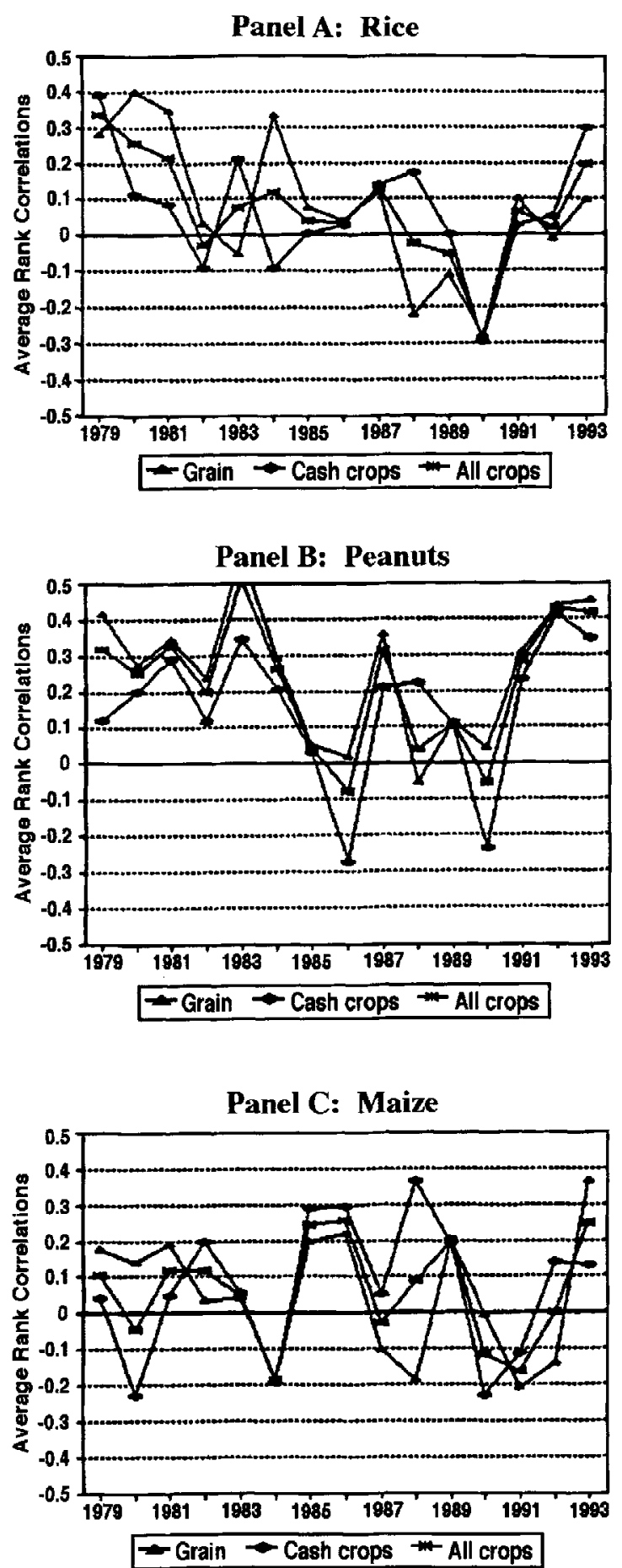

Source: Sown area and yields from ZGTJNJ, 1980-95.

Figure 2. Movement toward comparative advantage of major grains using average rank correlations in China, 1979-94 a policy dilemma for government officials: Should officials increase their efforts to regain control of the grain economy through retrenchment using traditional policy instruments even if it means reversing institutional reforms? Or, should policy makers establish new institutions and rules that preserve the allocative efficiency of markets while establishing better, albeit more indirect, control over resource flows?

In an increasingly commercial environment, the role of government is evolving so that its main job is to foster competition, stabilize prices, serve as an impartial arbiter of fair competition, and prohibit barriers to interprovincial trade. The government must continue to invest in public goods that promote market development-transport and communications infrastructure, market institutions such as wholesale and futures markets, the development of uniform quality standards for grain, and contract enforcement mechanisms. But, it is increasingly clear that the state does not need to continue to participate in commercial trade. One of the challenges of the government in the coming years is to separate its policy duties from ones which commetcial traders can do without government involvement.

\section{References}

Chen, J. "Several Problems in the Rural Areas Which Urgently Need to be Studied at Present." Liaowang 18(May 1994a):16-17.

Chen, X. "The Central Government's Politics and Measures are Good, But It Is Difficult to Implement Them at the Local and Departmental Level." Liaowang 18(May 1994b):13-16.

Duan, Y. "Reform: The Only Way for Agriculture to Get Out of Difficulty." Liaowang 18(May 1994):17-18.

Lardy, N. Agriculture in China's Modern Economic Development. Cambridge: Cambridge University Press, 1983.

Lin, J., F. Cai, and Z. Li. "Why China's Reforms Have Been Successful: Its Implications for Other Reforming Economies." Working Paper, Department of Rural Economy, Development Research Center, Beijing, China, 1994.

Nyberg, A. "Constraints on the Development of China's Grain Marketing Infrastructure." Paper Presented at the Conference on Market Economy and China's Agriculture. Fudan University, Shanghai, 7-8 December 1995.

Park, A., and S. Rozelle. "Commercialization of the 
State in Rural China." Paper presented at a conference on "Property Rights in Transitional Economies: Insights from Research in China." Hong Kong University of Science and Technology, 13-15 June 1996.

Park, A., S. Rozelle, and C. Fang. "China's Grain Policy Reforms: Implications for Equity, Stabilization, and Efficiency." China Econ. Rev. 5(Spring 1994): 15-34.

Rozelle, S., A. Park, J. Huang, and H. Jin. "Dilemmas in Reforming State-Market Relations in Rural China." Unpublished Working Paper, China Division, World Bank, Washington DC, 1996.

Sexton, R., C. Kling, and H. Carmen. "Market Integration, Efficiency of Arbitrage, and Efficient Competition: Methodology and an Application to U.S. Celery." Amer. J. Agr. Econ. 7(May 1991):568-80.

Sicular, T. "Redefining State, Plan and Market: China's Reforms in Agriculture Commerce." China Quart. 143(December 1995):1020-46.

Wan, G., and E. Cheng. "Integration in China's Rice Markets." Working Paper, University of Adelaide, 1996.

Watson, A. "China's Agricultural Reforms: Experi- ences and Achievements of the Agricultural Sector in the Market Reform Process." Working Paper 94/4, University of Adelaide, 1994.

Wu, S. "Implementation of Market Regulations Under the Macro Control of the State-The Key to Carrying Out China's Grain Development Strategy." Paper presented at the conference, Market Economy and China's Agriculture: Problems and Prospects. Fudan University, Shanghai, 7-8 December 1995.

Zhong, F. "A Review of Recent Grain Reforms in Rural and Urban Areas." Working paper, Department of Agricultural Economics, Nanjing Agricultural University, Nanjing, China, 1994.

ZGGSXZGLTJ. Zhongguo Gongshang Xingzheng Guanli Tongji Sishinian (Forty years of statistics of China's market administration and management). State Statistical Bureau Press: Beijing, China. 1992.

ZGSYNJ. Zhongguo Shangye Nianjian (China commercial yearbook). Beijing, China: Ministry of Domestic Trade Press, 1990-94.

ZGTJNJ. Zhongguo Tongji Nianjian (China statistical yearbook). Beijing, China: China Statistical Press, 1981-95. 